\title{
Criminal Implications of Corruption on The Misuse of Village Fund In The Village Government
}

\author{
Tjut Dhien Shafina \\ \{shafinacut@gmail.com\} \\ Doctor of Law, Universitas Jayabaya, Jakarta, Indonesia
}

\begin{abstract}
Village fund management allocated for village development will be one of the factors that drive the whole national development. On the other hand, the law enforcement against misuse of village funds is inhibited by some procedural constraints, differences in interpretation, inconsistencies, and conflict of norms between village laws and regulations will hinder development. Law enforcement on the misuse of village funds in order to achieve national goals is essential. However, criminal responsibility for misuse of village funds as a criminal act of corruption explained in PTPK Law does not conform with the specificity of the village as a legal community unit which has the authority to regulate and handle government affairs. This research used normative juridical research method, in which secondary data were analyzed. The results showed that the current accountability model for misuse of village funds has not been able to develop legal certainty due to the absence of Village regulation that can distinguish between accountability models for misuse of village funds based on the aspects of accountability for administrative law, civil law, and criminal law. This issue leads to legal uncertainty both in the theory and practices of law enforcement.
\end{abstract}

Keywords: Village Fund; Law Enforcement; Criminal Act of Corruption

\section{Introduction}

Indonesia's village governance is regulated by Government Regulation Number 43 of 2014 concerning Villages. The regulation regulates the obligations of the city government to formulate local regulations on Village Funds as part of the village's fiscal authority in regulating and managing their finances. The important thing in this regulation is that the financial activity and budgeting process should be held accountable.

Meanwhile, Indonesia's decentralization policy has affected the relationship between stakeholders in a region, ranging from the government, the private sector to the community. This environmental context, which is the relations between the private sector, government and society, heavily contributes to creating a business climate and enable the regional government to seize domination. That is, local governments have a massive role and responsibility in creating a conducive investment climate through local economic governance.

The decentralization policy was strengthened by the Decree of the Minister of Home Affairs and Regional Autonomy Number 50 of 2000 concerning Guidelines for the Organization and Work Procedures of Provincial Regional Apparatus. That decree is the basis for managing all regional resources and should be maximally utilized by regions granted autonomy rights from the central government. This opportunity is very beneficial for regions with enormous natural 
resources as it allows them to manage their territory independently. This decentralization effectively enables regional governments to exercise the principles and ideals of regional autonomy. Missions like creating appropriate welfare, an established democracy, increasing the independence of the autonomous region in developing its regional potential to encourage the role of the regional legislature in carrying out their functions (supervision, budgeting, and legislation), will be realized easier. That is, policies can be made and adjusted according to the needs of the people in the area.

However, the village fund given annually to all villages must be held accountable. Financial accountability is an important dimension in village fund use since the villages used to receive limited financial assistance for their regional development, and that their management used to be simple, while the current village fund program grants them a large sum of the fund and a broader chance of managerial independence.

To prevent misuse of village funds, the Directorate of Research and Development of the Corruption Eradication Commission (Komisi Pemberantasan Korupsi-KPK) conducted a study in 2015 on Village Financial Management. The KPK conducted their observations in five regencies, including Bogor, Klaten, Kampar, Gowa and Magelang. The study investigates the system and financial management, and it is based on Village Fund Allocation (Alokasi Dana Desa-ADD) and Village Funds. This study is ordered by Law Number 6 of 2014 concerning the village, leading to the approval of a budget of 20.7 trillion Rupiah in 2015 by the Revised Indonesia State Budget (Anggaran Pendapatan dan Belanja Negara Perubahan-APBNP), which will be distributed to 74,093 villages across Indonesia. As of April 2015, the government has distributed the first phase village funds to 63 districts worth more than 898 billion Rupiah. From a study conducted in January 2015, the KPK reported 14 findings on four aspects such as regulation and institution, management, supervision, and human resources.

Furthermore, based on the Indonesia Corruption Watch (ICW) monitoring as of August 2017,112 village chiefs were mostly the main actor in the misuse of village funds. The number has increased since 2015 by 15 people, from 32 people in 2016 to 32 people, and to 65 people in 2017. Other perpetrators included 32 village officials and 3 family members of the village chief. Based on their monitoring, there has been an exponential increase of misuse fund cases from 2015 to 2017. In 2015, there were 17 cases, but it rose to 41 cases in 2016 and 96 cases in 2017. That is, within three years, there were 154 cases in total.

Meanwhile, the losses due to corruption in village fund misuse in 2015 reached 9.12 billion Rupiah. In 2016, it reached 8.33 billion Rupiah, and in 2017, it accounted for 30.11 billion Rupiah, bringing the total to Rp. 47.56 billion of loss within three years. The factors attributed to the cause of corruption in the village sector are lack of community involvement in the village budget planning and monitoring process, unoptimized village council, the limited competence of the village chiefs and their officials, and the high political costs of chief elections.

In terms of regulation and institution, the KPK identified numerous problems. Firstly, there is incomplete regulations and technical guidelines for implementation that are necessary to village financial management. Secondly, there is a potential overlapping authority between the Ministry of Villages and the Directorate General of Village Government Development at the Ministry of Home Affairs. Thirdly, the formula of Village Fund distribution in Government Regulation number 22 of 2015 is considerably opaque and only based on "equal distribution." Fourthly, the base income sharing arrangements for village officials from ADD found in the Government Regulation number 43 of 2014 is relatively unjust. Finally, there is inefficiency in the accountability reports due to overlapping regulatory provisions.

Against that background, criminal responsibility for the misuse of village funds to achieve national goals is necessary. However, indictment for the misuse of village funds as regulated in 
the Corruption Eradication Law (Undang-undang Pemberantasan Tindak Pidana Korupsi-UU PTPK) is incongruent with the role of the village as a legal community unit. Principally, a village in Indonesia has the authority to regulate 1) government affairs, 2) interests of local communities based on community initiatives, 3) rights of origin, and 4) traditional rights recognized and respected in the government ecosystem of the Republic of Indonesia. This is reaffirmed in Law Number 6 of 2014 concerning Villages (after this referred to as the Village Law) that a village has rights of origin and traditional rights in regulating and managing the local community's interests and fulfilling the ideals of the independence based on the 1945 Constitution.

The legal policy for the application of corruption and the absence of a separate criminalization arrangement against the misuse of village funds can be an obstacle for achieving village development goals such as advancing the economy of the village community and overcoming national development gaps.

\section{Research Methods}

This study applied normative juridical research methods (normative law research). The normative case considered was in the form of legal behaviour products by reviewing laws. The study aims to conceptualize the law as norms or rules applied in society and can be a code of conduct. In this study, after the legal materials were collected, they were analysed to draw a conclusion. The analysis technique was content analysis.

\section{Results and Discussion}

The Village Law limits a village government as the administrator of government affairs regarding the local community's interests in the government system of the Republic of Indonesia. Its head of government is the village chief, assisted by his officials as an element of village government administrators. The position of the village chief in the Indonesian constitution, in a narrower sense, can be understood as the administrator that serves the regional community within the broader framework of governance. This foundation separates the regional government units given autonomy from the legal community units. The affairs managed by the regional government units represent a dispersion of power and recognition. Certainly, it is still possible for the regency, province, and the central government to delegate assistive duties to the villages.

Village finance is all the rights and obligations of the village in a monetary value, including goods and money related to the village's rights and obligations. Village financial management is set within one budget year from January 1 to December 31 . This process obeys a principle of transparency which means a principle of openness for the public to access unimpeded information regarding regional finance. Transparency guarantees the freedom of everyone to obtain information about the implementation of government's activities, which is, in this case, information about the process of making and implementing policies, as well as the results achieved.

Based on Article 2 to 13 of Corruption Eradication Law, corruption is classified into 30 forms and broadly classified into two types: two types of delik (delict-offense), which regulate the acts that are detrimental to state finances or the country's economy, and 28 other types which regulate the state's code of conduct regarding their authority of administration. 
However, the status of financial loss in the regulation is legally uncertain. This is because there is no distinct definition of what a state financial loss means in the General Provisions of the Corruption Eradication Law and the elaboration of the articles. Meanwhile, Article 32 paragraph (1) formulates that what is meant by "there has been a loss in state finance" as a loss calculated based on the findings of the authorized agency or appointed public accountant. Nevertheless, this formula does not formulate the definition of "state financial loss". Instead, it only confirms that such an actual event of state financial loss has transpired.

The KPK has filed at least 14 potential problems that encompass aspects such as regulation and institution, management, supervision, and human resources. ICW, a non-governmental organization, in its annual report, identifies seven forms of corruption that happened within the framework of the village government, ranging from embezzlement, budget abuse, abuse of authority, illegal fees, mark-ups, fictitious reports, budget cuts to bribery. The seven forms of corruption indicate that there are five corruption-prone points in managing village funds. The five corruption-prone points are as follows:

1. Planning process;

2. Accountability process;

3. Monitoring and evaluation process;

4. Implementation process;

5. Procuring goods and services in channelling and managing village funds.

Criminal responsibility should consider that criminal law must be utilized to create a just and prosperous society with material and spiritual equality. Such criminal law must enable the prevention of those unwanted acts. In addition, the use of criminal law that facilities negative sanctions must pay attention to the costs and capabilities of the relevant institutions so that there is no overcharge of burden (overbelasting) in the implementation process. Criminal responsibility is a mechanism to determine whether the defendant or suspect is responsible for a criminal act.

However, the Village Law has not yet regulated a separate criminal responsibility, resulting in several cases of misuse of village funds that touch upon the implications for corruption in the framework of the Corruption Eradication Law. Based on these perspectives of legal certainty, conflicting norms, and unclear juridical boundaries, the form of criminal responsibility for the misuse of village funds can affect legal uncertainty and justice in the management of village funds. The author agrees with Romli Atmasasmita that states that not all Administrative Penal Laws can constitute a criminal act of corruption. Moreover, to determine it as a criminal act of corruption, it must be guided by the provisions of Article 14 of the Corruption Eradication Law.

The Village Law has regulated material regarding the Principles of Regulation, Village Position and Type, Village Arrangement, Village Authority, Village Administration, Village Community Rights and Obligations, Village Regulations, Village Finance and Village Assets, Village and Rural Area Development, Village-owned Enterprises, Village Cooperation, Village Community Institutions and Village Traditional Institutions, as well as Guidance and Supervision. In addition, this law also provides special provisions that only apply to Traditional Villages as stipulated in Chapter XIII. However, the Village Law does not explicitly regulate the accountability model for the abuse of village finances and assets, including village funds. The implication is that when there is no clear and firm regulation regarding the accountability model for the misuse of village finances and assets, law enforcements are elicited to consider the misuse of village funds as a criminal act of corruption. Institutional efforts to enforce the 
law on misuse of village funds need to be supported by a clear and firm regulatory framework to ensure that the law enforcement process proceeds to create legal certainty that fulfils the community's sense of justice.

Criminal law reform has now become an urgent need for fundamental changes to achieve the goals of crime, action, policy and punishment. Accountability for the misuse of village funds in legal reform needs to be done by drafting the Village Bill. Satjipto Rahardjo explained that the essence of law enforcement is a process to bring legal aspirations or ideas into existence. Legal desires are the thoughts of a legislative body in the form of ideas or concepts about justice, legal certainty and social benefits formulated in that legal regulation.

\section{Conclusion}

The study found that the current accountability model for the misuse of village funds has not yet effective to guarantee legal certainty since the Village Law does not yet have a regulation that can distinguish between accountability models for misuse of village funds based on aspects of accountability for administrative law, civil law, and criminal law. Thus, it can cause legal uncertainty both in theory and the praxis of law enforcement.

\section{References}

[1] Atmadja, A. T., \& Saputra, A. K. (2017). Pencegahan Fraud dalam Pengelolaan Keuangan Desa. Jurnal Ilmiah Akuntansi dan Bisnis, 12(2), 7-16.

[2] Kusuma, H. (2016). Desentralisasi Fiskal dan Pertumbuhan Ekonomi di Indonesia. Desentralisasi Fiskal dan Pertumbuhan Ekonomi di Indonesia, 9(1), 1-11.

[3] Sulumin, H. H. (2015). Pertanggungjawaban penggunaan alokasi dana desa pada pemerintahan desa di Kabupaten Donggala. Katalogis, 3(1).

[4] Suwarno, S. (2019). Pengelolaan keuangan desa: Perencanaan sampai dengan Pertanggungjawaban pada desa di Kecamatan Cilongok Banyumas. Jurnal Riset Akuntansi \& Perpajakan (JRAP), 6(01).

[5] Hattu, J. (2020). Pertanggungjawaban pidana pengambilan jenasah covid-19 secara paksa berdasarkan aturan tindak pidana umum dan tindak pidana khusus. Jurnal Belo, 6(1), 11-31.

[6] Kitab Undang- Undang Hukum Pidana 